\title{
Marketing Practices and Their Effects on Firm's Performance: Findings from Small and Medium Sized Catering and Restaurants in Karachi
}

\author{
Arsalan Mujahid Ghouri \\ MS Graduate, Faculty of Management and Social Sciences, Institute of Business and Technology \\ Karachi, Pakistan \\ E-mail: arsalan.ghouri@ymail.com \\ Naveed Ur Rehman Khan (Corresponding author) \\ Lecturer, Faculty of Management and Social Sciences, Institute of Business and Technology \\ Karachi, Pakistan \\ E-mail: naveed.r.khan@gmail.com \\ Dr. Muhammad Abdul Malik \\ Professor, Federal Urdu University of Arts, Science and Technology, Karachi, Pakistan \\ E-mail: muhammadabdulmalik@gmail.com \\ Ambreen Razzaq \\ MS Candidate, Faculty of Management and Social Sciences, Institute of Business and Technology \\ Karachi, Pakistan \\ E-mail: ambreen.razzaq@yahoo.com
}

Received: November 22, 2010 Accepted: December 7, 2010 doi:10.5539/ijbm.v6n5p251

\begin{abstract}
Marketing should be called as the competitive edge of every business. Marketing practices are differing from continent to continent, countries to countries, cities to cities and sector to sector in relation with social, cultural and economic backgrounds. The differentiation among space, time and effectiveness of marketing practices could be the distinction for any firm or business in particular environment. Different approaches of marketing planning and practices are used in different phases of the company's life.

In Karachi, majority of small businesses and even some big corporate companies involved in peculiar marketing practices. In this study the Marketing benefits, its role and results are addressed in the context of Restaurant and Caterers business. The objective of the study is to determine the effects of existing marketing practices of restaurant and catering businesses on their performance and their commerce. The aim of this study is to analyze the vague marketing practices and its effect on restaurant and catering business and their performance in Karachi.
\end{abstract}

Keywords: Marketing practices, SMEs, Catering industry, Restaurants, Firm's performance, Karachi

\section{Introduction}

Karachi is the leading city of Pakistan having population of 13.125 million people, United Nations declared Karachi as the $10^{\text {th }}$ world's largest city by population. Karachi generated $46.75 \%$ of direct taxes, $33.65 \%$ of Federal excise taxes and $23.38 \%$ of domestic sales tax in the year 2006-2007 as reported by Federal Board of Revenue. Furthermore, Karachi contributes 30\% in manufacturing sector of Pakistan and 90\% in Sindh's GDP and 
around $20 \%$ of the total GDP of Pakistan. Hence, it is safe to say that Karachi is the financial and business hub of Pakistan, providing millions of economic opportunities.

The Catering and Restaurants business have been contributing in economic cycle since independence of Pakistan. Major openings of Catering and Restaurants business have been noticed in early 90s. In 1999 Foreign Agricultural Service GAIN reported that 11 million people used to go to hotels \& restaurants daily for lunch and dinner in Pakistan. The popularity of fast food, western food and Chinese food have been grown since the successful establishments of national / international food chains in major cities of Pakistan.

Marketing the way most textbooks treat it today was introduced around 1960s along with the concept of the marketing mix and four P's of marketing - product, price, place and promotion (McCarthy, 1960). Marketing practices may contribute in the growth of business in many aspects, if practice efficiently, like increase in volume of sales, mount in return on investment and maintain goodwill.

Proper marketing strategy(s) add excellence in business activities and strengthen the competitiveness and market share (Ghouri \& Khan, in press). To ameliorate the business, entrepreneur or top management should apply marketing tactics to grow their business. Marketing generally launch a campaign for an item/location, etc. From TV to banners for create a certain sense by providing money to the local cricket team, Marketing does it all.

O'Sullivan, Abela \& Hutchinson (2009) mentioned in their study, that the challenges faced by marketers are their inability to demonstrate the effectiveness of marketing activities. It is very difficult to anticipate the changes that are likely to be occurred in the marketing situation during the tenure of a firm's marketing plan and it is even more complex to analyze and predict changes for the entire market (Dhanani \& et al., 1997).

\section{Literature Review}

Restaurant and Catering businesses considered profitable business in Karachi. Unfortunately, there is not much official data available for caterers and restaurant businesses. According to Khan (2004), "There are around ten caterers in Karachi with strong customer bases consist of: La Rosh, Rajput, Handi, Mezban, Lal Qila, Karachi Caterers and Mela and over 3,000 caterers in the city, who are providing catering services at small or big level". Approx 350-400 local restaurants in Karachi including, Pizza Next, Pizza Expert, AFC, Lasania, Usmania, Al-Habib, Makka and Largees etc have been involved in large scale production; however, marketing strategies have not been properly applied in restaurant and catering businesses in Karachi. In these businesses, usually one person often responsible for developing the marketing plan(s). However, unfortunately these businesses are operating as a mass marketer as adopted strategy are same for all type of customers, which is not an appropriate strategy for globalize people of Karachi.

Pakistan has a major problem in literacy (Pakistan Economic Survey, 2006). That is why these problems arise regarding some basics knowledge of business. Hankinson (2000) mentioned education and skills are two of the major factors in organizational success.

It has been mentioned in various studies (Pakistan Economic Survey, 2005; Berry, 2002) that in Pakistan, the firms have not been using marketing as the tool for their business enhancement or support or expend. These businesses use to work on outdated guide line which they get from their old reliable sources (mentor, experience etc).

The Phonebook, one of the most reliable online database of Pakistan's businesses, mentioned three seventy seven caterers and six hundred and sixteen restaurants in Karachi. Khan (2004) wrote in his article that around 3000 caterers operating in this business in which ten big caterers who have major share of market specially Hanif Rajput Catering who has an asset base of approximately Rs. 5 billion and an inventory of furniture, crockery and transport worth Rs. 30 million (Kamal \& et al., 2005) and approximate 350-400 local restaurants in Karachi. According to Kamal, \& et al (2005) that 150 caterers are running their businesses with 150,000 employees. Every year the demand for the Catering Business will be going on increasing (Doyle, 2009).

Catering is one of the highest rising sectors (Jones, 2009) with restaurants in major cities of Pakistan. Hence, catering business may be a very profitable field and potential of investment (Skoglund, 2008). In Pakistan catering business has the potential of over Rs.40 billion per annum (Qureshi, 2004) Caterers said that the estimated daily turnover of the catering business in the city is in the range of Rs 6.5 million to Rs 7 million (Khan, 2004) in excess demand season, however, Javed Rajput, CEO Hanif Rajput Caterers, said that "catering business is still an unorganized sector, professionalism has really not permeated" (Kamal \& et al., 2005). By the 1990's the competition in the catering business became intense (Kamal \& et al., 2005) along with restaurants.

According to Farrukh (1999) 'Dining out' is growing in popularity in major cities of Pakistan. More than 11 million people dine out regularly. In the past, most local hotels and restaurants served traditional foods. Recently, however, ethnic and fast foods, including western-style/ Chinese style fast food, have become popular and an 
increasing number of fast food chains have been successfully established in the major urban areas. The sector is dominated by numerous and midsized Family restaurants in which $62 \%$ are family restaurants, $15 \%$ are fast food restaurants, $6 \%$ hotels and $17 \%$ are ethnics.

Restaurant and catering owner's marketing practices aren't at the top (Berry, 2002) in Karachi. They either don't do much about it, or they just follow the same old, ineffective and expensive ways to market themselves at Yellow Pages (Riesco, 2008). According to Linn (2004), in year 2000 McDonalds spent over \$1.3 billion on advertising in the United States alone, making Burger King's \$650 million. However, this is not in the case of Karachi or even Pakistan better to cite from Pakistani context as well. Kraft Foods (owned, incidentally, by tobacco giant Phillip Morris-now called Altria Group), maker of Kraft Macaroni and Cheese, Oreos, and Kool-Aid, spent about \$465 million in 2001 (as cited in Linn, 2004). In 2000, Burger King spent \$80 million on advertising just to children (Cebryznski \& Zuber, 2001). For instance, McDonald's food products were embedded in the hit children's film Spy Kids (Linn, 2004). Food companies also market to children through toys. Barbie dolls work at both Pizza Hut and McDonald's, Burger King, and the latter partners with Play Doh and Easy Bake (as cited in Linn, 2004).

\section{Research Questions}

The study will seek to get in depth answers of the following questions:

1. What major Marketing Practices are used and effect/ affect the restaurants/catering firms in Karachi?

2. How these Marketing Practices related to firm performance?

\section{The Research Framework}

After careful consideration, seven marketing practices and five headings/ contents which represent the performance of the firm are selected for examination, which are significant from restaurant and catering businesses perspective. In this research seven independent variables of marketing practices are examined and their effects on dependent variable, performance, are investigated.

Variables are selected from the available literature, marketing personnel and observation of researcher on lacking aspects of caterers and restaurants businesses. Seven independent variables of Marketing Practices are selected i.e. commercial relationship, segmentation, technology use, supply chain management, advertising, pricing, and public relations. Likewise, the dependent variable is Performance in terms of ROI (return on investment), Sales, Goodwill, Employee turnover/ satisfaction, Quality.

These variables are taken into consideration for getting up the research and analyze the results. Research model of marketing practices and firm's performance is shown in figure 1.

As indicated earlier that, seven independent variables (Marketing practices) are commercial relationship, segmentation, technology use, supply chain management, advertising, pricing, and public relations, and examine their effect/ affect on dependent variable Performance (ROI, sale, goodwill, employee turnover/satisfaction and quality) is investigated.

Based on research framework \& variables following hypotheses are derived and develop for the study.

H1: Commercial relationship, segmentation, technology, supply chain, advertising, pricing, and public relation practices are associated positively to firm performance.

$\mathrm{H} 2$ : Marketing practices of restaurants and caterers business associated positively to firm performance.

\section{Methodology}

\subsection{Sampling and Data Collection}

Due to time constrain, random sample technique is applied, in which a sample represents the actual population. Seven areas where restaurant and catering business are established was visited for the survey which includes, Nazimabad, Tariq Road, Clifton, Gulshan e Iqbal, Gulistan e Johar, Defense and Water pump. Since the survey was self-administered and researchers personally visited the respondents' place for survey purpose out of 126 questionnaires 124 were completely filled which is $98 \%$ of total, however, two questionnaires were not filled due to the cold response of respondents. Out of total 124 questionnaires $101(81 \%)$ questionnaires were found complete and correct for results analysis, remaining 23 questionnaires were rejected.

\subsection{Questionnaire Design}

Data collected via use of questionnaires. The survey questionnaire was developed in English and translated into Urdu as well. The introductory letter introduced the researcher and the reason of research and also ensures the secrecy of the respondent's private information with complete confidence. 
The survey questionnaire was composed of three sections. Section one collects the demographic information, section two collects the responses on independent variables and section three collects the responses on dependent variable.

\subsection{Reliability Testing}

To measure the reliability of the instruments used, Cronbach's alpha is employed. According to Sekaran (2005) instrument is acceptable for analysis if Cronbach's alpha is greater than 0.6 and is within 0.7. The result of reliability testing of the instrument used in this study is 0.68 ; hence, it is acceptable for further analysis.

\subsection{Data Analysis}

Data analysis completed by using statistical package for social sciences (SPSS) version 14 for Windows XP. Since it is an exploratory study descriptive analysis were carried out to portray the profile of respondents. Hypothesis one tested by using correlation analysis while hypothesis two tested by regression analysis which used to test the impact of the marketing practices on firm performance.

\section{Research Findings}

\subsection{Background of respondents}

The overall profile of the participating respondents' demographic characteristics is discussed below:

In perspective of catering and restaurants businesses in Karachi, 50 are caterers $(49.50 \%)$ and $51(50.50 \%)$ are restaurants in 101 business entities which was investigated. 'Owners' dominate in respond by $45(44.55 \%)$ out of 101 , 'marketing manager' total was $25(24.75 \%)$, 'other manager' $11(10.89 \%)$ and 'others' respondent are 10 (09.90\%). 99 respondent are 'male' (98.02\%) and only 2 (01.98\%) are 'female', this shows that male gender dominating the caterers and restaurant businesses and are more willing to participated in these businesses.

Out of 101 respondents, 34 (33.66\%) belong to ' 61 and more' age group, 21 (20.79\%) from '41-50' age group, $20(19.80 \%)$ from ' $31-40$ ' age group, $18(17.82 \%)$ from ' $51-60$ ' age group and $8(07.92 \%)$ from 'less than 31 ' age group. The majority of participants $(80.20 \%)$ are 'married', and (19.80\%) are 'single'.

Education level was really a field of concern for top management of caterers and restaurants business. As far as academic qualification is concern 46 respondents $(45.54 \%)$ have the education level of 'intermediate', 21 (20.79\%) have 'graduate' degree, 18 (17.82\%) respondents have passed 'matriculation', $9(08.91 \%)$ have the education level of 'masters or above' and $7(06.93 \%)$ respondents were 'under matriculation'. This showing that education level is lacking in caterer and restaurant businesses.

Tenure in company/ business shows, 3 (02.97\%) respondents have the tenure of 'less than 6 months', 4 (03.96\%) have the tenure of ' 7 months- 24 months', 14 (13.86\%) are working/ owning from ' 25 months-42 months', 22 $(21.78 \%)$ have ' 43 months-60 months' tenure and 58 (57.43\%) have the tenure of ' 61 or more'.

\subsection{Descriptive statistics of variables}

Table 1 highlights descriptive statistics of the main variables of the present study, i.e. performance (from marketing activities/ dependent variable), and independent variables: commercial relationship practice, Segmentation practice, technology use practice, supply chain management practice, advertising practice, pricing practice and public relation practice.

As can be seen from the table, the respondents generally perceived that they are getting positive results (highly moderate) from their marketing activities (performance) $($ mean $=3.478, \mathrm{SD}=.601)$

But they perceived that they insignificantly involve in commercial marketing practice (mean $=2.833, \mathrm{SD}=.763$ ), technology use (mean $=2.852, \mathrm{SD}=.818)$, supply chain management practice (mean $=2.991, \mathrm{SD}=.562)$ and public relation practice $($ mean $=2.851, \mathrm{SD}=.752)$.

Participants supposed that they moderately involve in segmentation practice (mean $=3.224, \mathrm{SD}=.962$ ), advertising mean $=3.387, \mathrm{SD}=.665$ ), and pricing mean $=3.447, \mathrm{SD}=.461$ ).

Graph 1 elaborates this table as well to understand the figures easily. In the following section, each variable will be examined in greater details.

\subsection{Marketing practices effect on performance}

As indicated earlier, five items were used to measure the perceived involvement and importance of marketing activates with performance. Table 2 highlights the descriptive statistics for each item. All five items show the moderate responses/ results, highest average value is of, marketing activities are intended to increase or maintain company's sales $($ mean $=3.987$, standard deviation $=.359$ ), followed by, marketing activities are intended to 
increase or maintain our goodwill (mean $=3.438$, standard deviation $=502)$, marketing activities are intended to increase or maintain business's' ROI (mean $=3.428$, standard deviation $=.866$ ), marketing activities are intended too increase or maintain our quality (mean $=3.405$, standard deviation $=.657$ ) and marketing activities are intended too increase or maintain our employee turnover/ satisfaction (mean $=3.132$, standard deviation $=.621$ ).

In general, the responses appear moderate about performance by different marketing activities.

\subsection{Correlation matrix}

This study examines the nature of the relationship that exists between independent and dependent variables. Pearson correlation runs to determine the relationships amongst the variables. As a result, a correlation matrix is presented in table 3 .

As can be seen from table 3, all independent variables show a negative and significant relationship to performance of firm (cater or restaurant) by marketing activities except advertising practice. This means that commercial relationship, segmentation, technology use, supply chain management, pricing and public relation activities isn't use significantly to search out the maximum benefits. However, only advertising used as beneficial tool of marketing in caterers and restaurant businesses.

\subsection{Hypotheses testing}

As mentioned earlier, there are two hypotheses formulated for this study. To test the first hypothesis, Pearson correlation test was used, and for this, table 3 displays the correlation matrix is referred to. Both hypotheses were rejected only one variable of hypothesis one is supported since hypothesis one is depending upon seven variables, the fifth variable (Advertising) shows the significant relationship with firm's performance. The results reveal a significant and negative relationship between performance effect, (a) positive commercial relationship $(r=-.287$, $\mathrm{p}=.000)$, (b) positive segmentation relationship $(\mathrm{r}=-.288, \mathrm{p}=.000)$, (c) positive technology use relationship $(\mathrm{r}$ $=-.488, \mathrm{p}=.000),(\mathrm{d})$ positive supply chain management relationship $(\mathrm{r}=-.409, \mathrm{p}=.000)$, (e) positive pricing relationship $(\mathrm{r}=-.467, \mathrm{p}=.000)$ and $(\mathrm{f})$ positive public relation relationship $(\mathrm{r}==.393, \mathrm{p}=.000)$. Fifth variable (Advertising) of hypothesis one was accepted because there is significant relationship between advertising practice and performance of firm $(\mathrm{r}=-.147, \mathrm{p}=.104)$.

\subsection{Multiple regression analysis}

To test the second hypothesis, multiple regression was used for employing the Enter method. The idea here is to estimate the variance explained in performance of firm seven dimensions/ tools of marketing activities. Seven activities of marketing practices i.e. commercial relationship, segmentation, technology use, supply chain management, advertising, pricing and public relation were included in the regression model using a default enter method, to calculate the effects of variance caused on performance (dependent variable). The results are shown in table 4.

The results from table 4 indicate that the multiple regression coefficients $(R)$ of the seven independent variables of marketing activities to effect on performance of firm model is .563 and the adjusted R square is .182 . The value of $\mathrm{F}$ is 6.72 at $(\mathrm{p}<.05)$. This means that 18.2 percent of the variance in performance of firm has been significantly explained by the seven factors of marketing activities.

\section{Discussion}

One of the prime very first objectives of this study was to examine the level (score) of marketing practices and their effect on firm performance. It is found that the mean scores of all independent variables of marketing practices range between 2.83 to 3.44 . This indicates that seven factors of marketing practices are falling between insufficient to moderate level on a five-point scale. This is an indication that the marketing practices are not handled properly which could increase firm's performance.

With regard to performance, the mean value of 3.47 on a five- point scale point out that businesses have intentions to increase the performances by marketing efforts. However these findings further suggests that it is highly likely that some businesses start to invest in marketing activities for better firm performance.

\section{Conclusion}

Consistent with the findings of the study, it proved the researchers' point of view and concluded that only advertising (marketing) practice is positively associated with firm performance. In other words, it can be inferred that other practices except advertising are the waste of money and time for the small and medium sized Catering and Restaurants businesses. This is an old view that advertising has its natural effect as Powers (1903) posits that advertising has standardized effect which make people familiar with product/ service and their special features 
and they are willing to pay for it. This is authors' observation that these Pakistan businesses are cashing that effect because majority of owners/ managers/ caretakers are at low-altitude of literacy.

The alarming results of this study cannot be neglected and may be avail as opportunities for Catering and Restaurant businesses as Cludts (1999) illustrated in his study that response/ feedback of stake holders is essential to grow, which is lacking by targeted segment of Karachi's Catering and Restaurants. Moreover, Carter (2008) inferred that necessitous of public relations could be the cause of losing customers, as this study reveals, which ultimately effect the firm's performance in terms of decrease in sales. Yeung (2009) advised about the proper segmentation of the business otherwise business may lose available opportunities. Furthermore, Tukey (2002) emphasize on differentiation in business with all stakeholders in general and suppliers and customers in particular.

Last but not least, M-commerce marketing will be a good idea to market and expend business. Text messages/ sms facility is available in quite inexpensive rates, thus caterers and restaurants may expend their visibility in all over the city (Ghouri \& Khan, in press). Hiring of sales force could be another prolific stride for caterers and restaurants business. Sale force stimulus gets businesses and contracts from giant and local companies, which could resulted in multiplying the investment on sale force. Claim those aspects in marketing campaigns which are fulfilling at extreme levels. That makes trust between business and customers.

Hence Catering and Restaurant businesses should adopt new strategies which may help to overcome the lacking in their marketing activities which have overall impact on firm's performance.

\section{Limitations of the study}

The major limitation is related to the selection of sample population and the method of sampling of this study. The study gathered the data from the 101 caterers and restaurant businesses from seven main areas of Karachi. The caution must therefore be taken when generalizing the results of this study to the entire caterers and restaurant businesses in Karachi.

Self-administered surveys (questionnaire) were used to collect data from the sample population. One of the hazards associated with this method was the involvement of biasness; the researcher involved few times in helping respondents to make them understand the questions asked, and sometimes the other factors like the low level of knowledge of Marketing/ education strikes and took help of other by respondent to fill up the instrument. Therefore a bias may be generated in the process of collecting the information. Since the involvement of researcher's, lack of knowledge/ education and responding questionnaire may influence respondent's selection of particular answers to the questions, therefore a caution must be taken before generalizing the findings of this study.

\section{References}

Abedullah, M. A., \& Bukhsh, K. (2007). Issues and economics of poultry production: A case study of Faisalabad Pakistan. Pakistan Veterinary Journal, 27(1), 25-28.

Berry, A. (2002). The Potential Role of the SME Sector in Pakistan in a World of Increasing International Trade. The Pakistan Development Review, 37(4), 25-49.

Carter, T. (2008). Managing Retention. Journal of Hospital Marketing \& Public Relations, 18(1), 89 - 112.

Cebryznski, G., \& Zuber, A. (2001). Burger Behemoths Shake Up Menu Mix. Marketing Tricks. Nation's Restaurant News, February 5: I.

Cludts, S. (1999). The Stakeholders as Investors: A Response to Etzioni. Business Ethics Quarterly, 9(4), 673-676.

Dhanani, S., O'Shaughnessy, N., \& Louv. (1997). Marketing practices of UK high technology firms. Logistics Information Management, 10 (4), 160-166.

Don O'Sullivan, D., Abela, A. V., \& Hutchinson, M. (2009). Marketing performance measurement and firm performance: Evidence from the European high-technology sector. European Journal of Marketing, 43 (5/6), 843-862.

Doyle, W. (2009). An Insider's Overview of The Catering Business. Amazine Articles, [Online] Available : http://www.amazines.com/article_detail.cfm/1104610?articleid=1104610 (October 09, 2009)

Farrukh, A. (1999). Pakistan HRI Food Service Sector: HRI Food Sector Report, Foreign Agricultural Service GAIN report, PK9036, 1-9. 
Ghouri, A. M., \& Khan N. R. (2012). Mobile Phone Customers Attitude and Commercial Marketing Channel-an Empirical Study in the Context of Pakistan. Journal of King Abdulaziz, University: Economics and Administration, $26(2)$, in press.

Hankinson, A. (2000). The key factors in the profiles of small firm owner-managers that influence business performance: the South Coast Small Firms Survey, 1997-2000. Industrial and Commercial Training, 32(3), 94-98.

Jones, P. (2009). Qualities of Good Caterer in Catering Business, The Free Library Articles, Retrieved October 09, 2009, [Online]

http://www.thefreelibrary.com/Qualities+of+Good+Caterer+in+Catering+Business-a01073990682

Available:

Kamal, R., Ather, S., \& Shahid. A. (2005). Catering Strategy: a study of Hanif Rajput. Market Forces, 1 (1), 1-8.

Khan, A. (2004). Caterers cash in on wedding season. The Daily Times, [Online] Available: http://www.dailytimes.com.pk/default.asp?page=story_24-1-2004_pg5_12 (June 18,2009)

Linn, S. E. (2004). Food Marketing to Children in the Context of a Marketing Maelstrom, Journal of Public Health Policy, 25 (3/4), 36.

McCarthy, E. J. (1960). Basic Marketing. Irwin, Homewood, Illinois.

Pakistan Economic Survey. (2005-06). Ministry of Economic Affairs, Islamabad Government of Pakistan.

Powers, J. O. (1903). Advertising. Annals of the American Academy of Political and Social Science, 22, Business Management, 58-62

Qureshi, F. (2004). Need to regulate the catering business, Daily Dawn, [Online] Available: http://www.dawn.com/2004/04/13/letted.htm\#7 (October 09, 2009)

Riesco, J. L. (2008). Restaurant Marketing Strategies. Riesco Consulting Inc, Renton, WA.

Sekaran, U. (2005). Research methods for business: A skill-building approach (4 ${ }^{\text {th }}$ edition). New York: John Wiley \& Sons.

Skoglund, S. (2008). Catering Business: How to Get Started, Amazine Articles, [Online] Available: http://www.amazines.com/article_detail.cfm/472163?articleid=472163 (October 09, 2009)

Tukey, L. (2002). Differentiation. The Phi Delta Kappan, 84, (1), 63-64.

Yeung, G. (2009). Hybrid Property, Path Dependence, Market Segmentation and Financial Exclusion: The Case of the Banking Industry in China, Transactions of the Institute of British Geographers, New Series, 34, (2), $177-194$.

Table 1. Descriptive Statistics of Variables $(\mathrm{n}=101)$

\begin{tabular}{|l|c|c|}
\hline Item & Mea & Standard Deviation \\
\hline Commercial marketing & 2.833 & .763 \\
\hline Segmentation & 3.224 & .962 \\
\hline Technology use & 2.852 & .818 \\
\hline Supply chain management & 2.991 & .562 \\
\hline Advertising & 3.387 & .665 \\
\hline Pricing & 3.447 & .461 \\
\hline Public relation & 2.851 & .752 \\
\hline Overall result & $\mathbf{3 . 0 8 4}$ & .712 \\
\hline Performance & 3.478 & .601 \\
\hline
\end{tabular}


Table 2. Marketing practices effects on performance

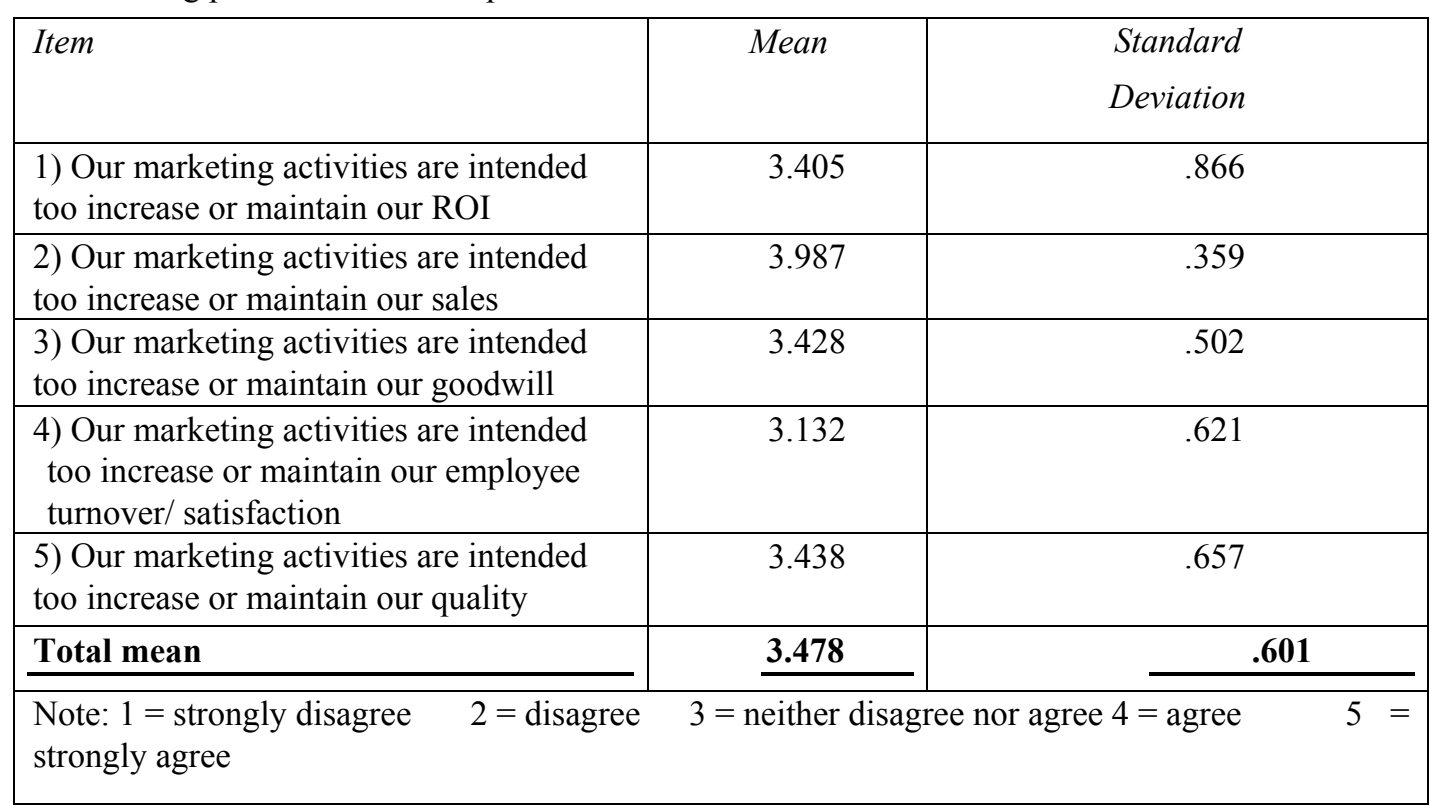

Table 3. Correlations Matrix $(n=101)$

\begin{tabular}{|c|c|c|c|c|c|c|c|c|}
\hline Activities......... & 1 & 2 & 3 & 4 & 5 & 6 & 7 & \\
\hline Commercial relationship & 1 & & & & & & & \\
\hline Segmentation & $\begin{array}{l}.457^{* * *} \\
\mathrm{p}=.000\end{array}$ & 1 & & & & & & \\
\hline Technology use & $\begin{array}{l}.597 * * * \\
\mathrm{p}=.000\end{array}$ & $\begin{array}{l}.501 * * * \\
\mathrm{p}=.000\end{array}$ & 1 & & & & & \\
\hline Supply chain management & $\begin{array}{l}.589 * * * \\
\mathrm{p}=.000\end{array}$ & $\begin{array}{l}.695^{* * * *} \\
\mathrm{p}=.000\end{array}$ & $\begin{array}{l}.457^{* * * *} \\
\mathrm{p}=.000\end{array}$ & 1 & & & & \\
\hline Advertising & $\begin{array}{l}.145^{* * *} \\
\mathrm{p}=.137\end{array}$ & $\begin{array}{l}.199 * * * \\
\mathrm{p}=.069\end{array}$ & $\begin{array}{l}.272^{* * * *} \\
\mathrm{p}=.000\end{array}$ & $\begin{array}{l}.189 * * * \\
\mathrm{p}=.109\end{array}$ & 1 & & & \\
\hline Pricing & $\begin{array}{l}.356^{* * *} \\
\mathrm{p}=.000\end{array}$ & $\begin{array}{l}.532 * * * \\
\mathrm{p}=.000\end{array}$ & $\begin{array}{l}.267 * * * \\
\mathrm{p}=.000\end{array}$ & $\begin{array}{l}.398^{* * *} \\
\mathrm{p}=.000\end{array}$ & $\begin{array}{l}.377^{* * *} \\
\mathrm{p}=.090\end{array}$ & 1 & & \\
\hline Public relation & $\begin{array}{l}.622 * * * \\
\mathrm{p}=.000\end{array}$ & $\begin{array}{l}.507 * * * \\
\mathrm{p}=.000\end{array}$ & $\begin{array}{l}.756^{* * * *} \\
\mathrm{p}=.000\end{array}$ & $\begin{array}{l}.581 * * * \\
\mathrm{p}=.000\end{array}$ & $\begin{array}{l}.699 * * * \\
\mathrm{p}=.000\end{array}$ & $\begin{array}{l}.367^{* * *} \\
\mathrm{p}=.000\end{array}$ & 1 & \\
\hline Performance & $\begin{array}{l}-.287 * * * \\
\mathrm{p}=.000\end{array}$ & $\begin{array}{l}-.288^{* * *} \\
\mathrm{p}=.000\end{array}$ & $\begin{array}{l}-.488^{* * *} \\
\mathrm{p}=.000\end{array}$ & $\begin{array}{l}-.409 * * * \\
\mathrm{p}=.000\end{array}$ & $\begin{array}{l}-.147 * * * \\
\mathrm{p}=.104\end{array}$ & $\begin{array}{l}-.467^{* * *} \\
\mathrm{p}=.000\end{array}$ & $\begin{array}{l}-.393 * * * \\
\mathrm{p}=.000\end{array}$ & 1 \\
\hline
\end{tabular}

Correlation is significant at the 0.01 level (1-tailed).

Correlation is significant at the 0.05 level (1-tailed).

Table 4. Multiple regression analysis

\begin{tabular}{|llcccc|}
\hline $\begin{array}{l}\text { Overall Influences of marketing } \\
\text { practices on firm performance }\end{array}$ & $R$ square & $\begin{array}{c}\text { Adjusted } R \\
\text { square }\end{array}$ & $\begin{array}{c}\text { Std. error of the } \\
\text { estimates }\end{array}$ & $F$ & Sig. \\
\hline .563 & .214 & .182 & 1.08624 & 6.72 & .000 \\
\hline
\end{tabular}




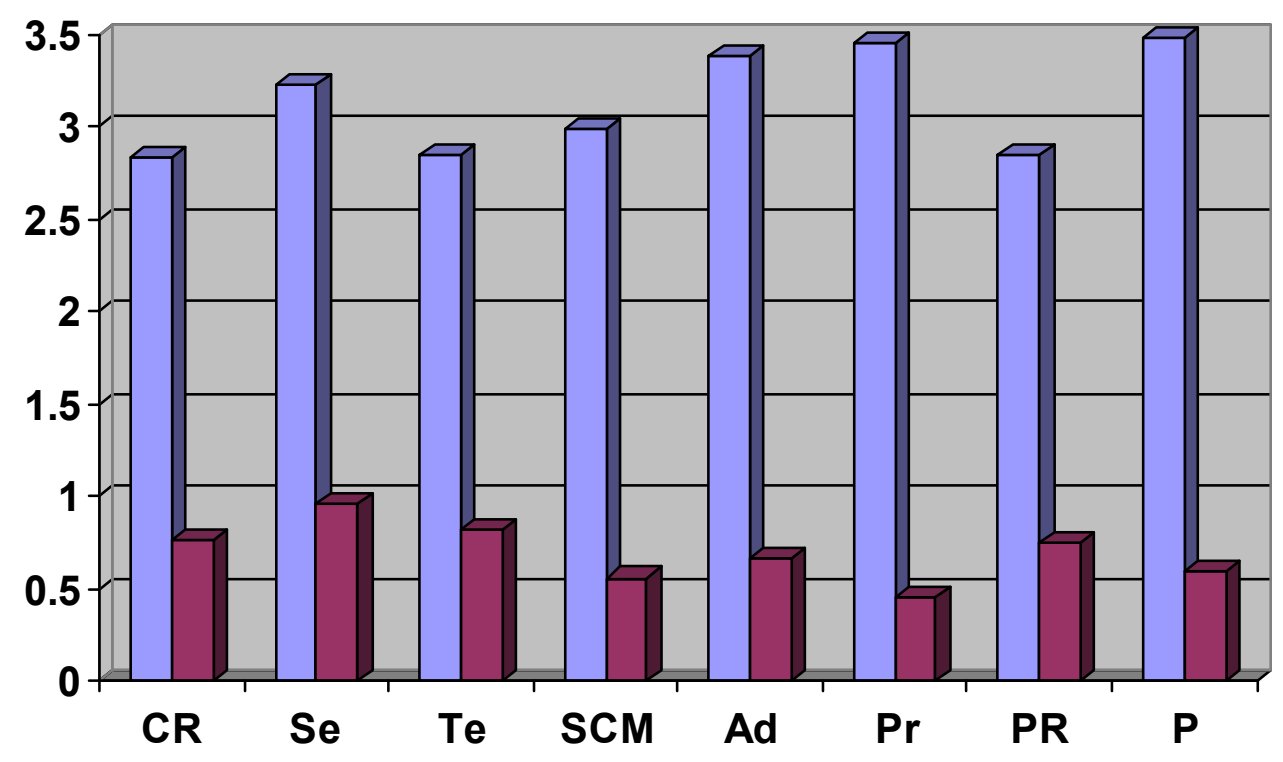

Graph 1. Descriptive statistics of variables

\section{Marketing}

Practices (IVs)

Commercial

Relationship
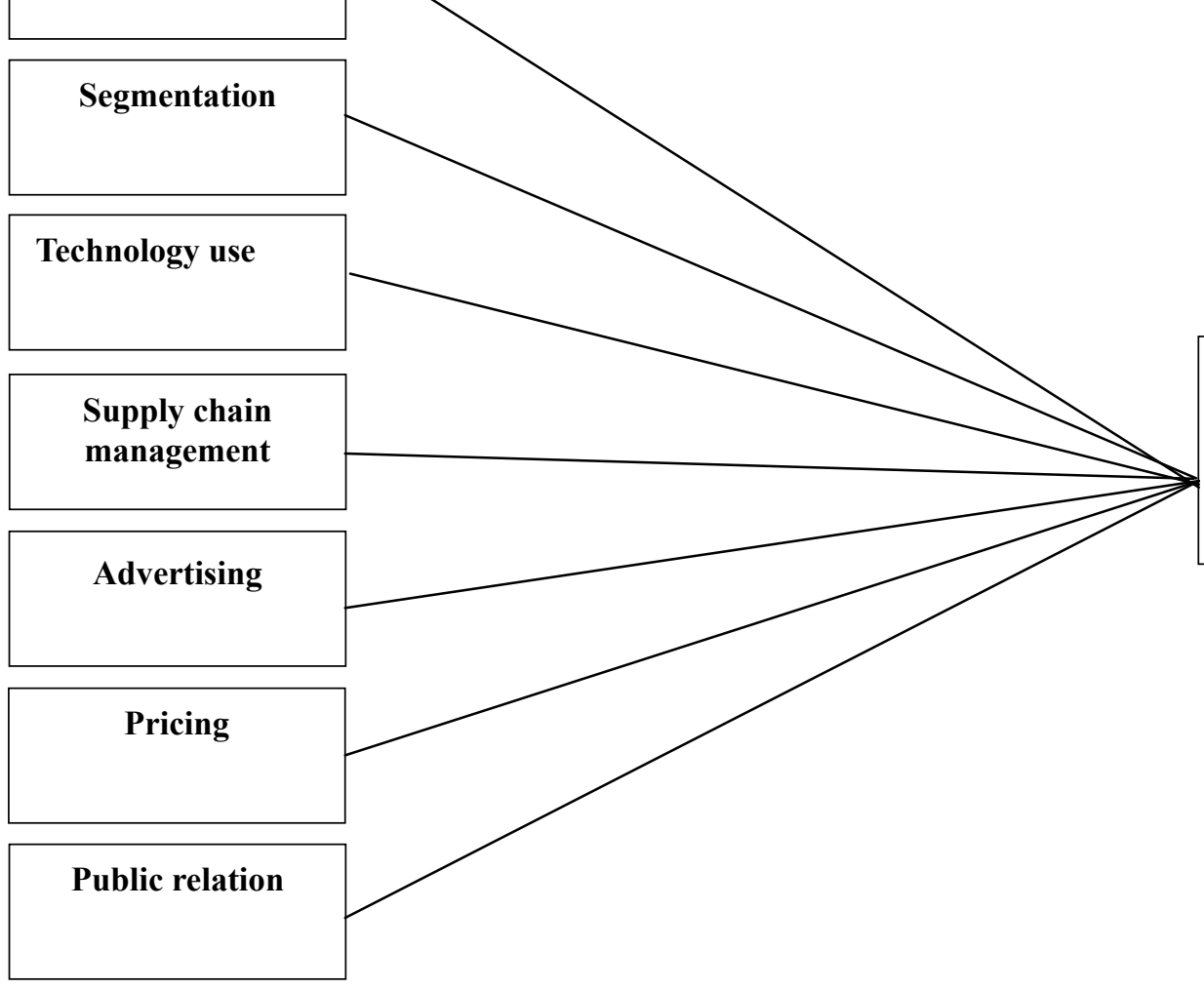

Performance

(DVs)

Figure 1. Research framework 